\title{
DARWIN'S VOYAGE THROUGH THE PROVINCE OF JURISPRUDENCE: A BEGUILING HYPOTHESIS
}

\author{
Sandra Petersson*
}

If we share a common ancestor, is it not reasonable to suppose the existence of common ancestral laws - at least at some point in our distant past? This paper proposes an (irreverent) evolutionist revision of John Austin's classification of law. In short, what if, instead of living next door to Jeremy Bentham, Austin had lived next door to Charles Darwin? How would that environment have changed Austin's analysis in The Province of Jurisprudence?

\section{INTRODUCTION}

The field of jurisprudence often concerns itself with two central questions. The first is what is law? The second is what is good law? My intent is to address the first question "What is law?" However, as HLA Hart cautions, while many have tried to define the essential nature of law, none have succeeded. ${ }^{1}$ So if the reader is not fully enlightened by this article, then I will have earned my place among eminent legal theorists.

As a Canadian, I grew up in the Province of Alberta. I studied law in the Province of Alberta. I was admitted to the bar of the Province of Alberta. One of the detrimental effects of this background is that I tend to think of the Province of Jurisprudence as a physical place somewhere you might want to go on sabbatical, but certainly not on vacation. The idea for this paper came from a beguiling daydream that it is a place where Charles Darwin might have voyaged on The Beagle.

* Senior Lecturer in Law, Victoria University of Wellington.

1 HLA Hart The Concept of Law (1 ed, Clarendon Press, Oxford, 1961) 2. 
As my title suggests, I will be drawing on the work of two very different theorists of the 19th century: John Austin, positivist, and Charles Darwin, naturalist. Austin, of course, explores the nature of law in The Province of Jurisprudence Determined, published in 1832 - a work whose significance to the study of jurisprudence has been such that many of us are only now beginning to realise that it is possible to admit that we have not read it. ${ }^{2}$ Many lawyers and, indeed, many legal academics will be more familiar with Darwin's exposition of the laws of nature than with Austin's exploration of the nature of law. Darwin's theory of evolution initiated a paradigm shift in Western thought, one so fundamental that we do not need to read Darwin to feign familiarity with his work. However, it is perhaps to Austin's credit that Clarence Darrow was never asked to defend the legality of teaching positivism in public schools. $^{3}$

Austin's work was heavily influenced by Jeremy Bentham, a close colleague and neighbour in Bloomsbury's Queen Square. Earlier scholars have observed the results of thinking inside the Square, cataloguing Bentham's and the Mills' influence on Austin, leaving little scope for original comment on the subject. ${ }^{4}$ That there is currently a much needed gap in Austinian scholarship generally is evidenced by the dwindling number of articles on Austin's theory, less than twenty in as many years. ${ }^{5}$ It is my intent to create and fill that gap by

2 Others have read it but seemingly do not admit to it in public for fear of appearing jurisprudish. As Hilaire Barnett reports, Austin was still read in depth in 59 per cent of British jurisprudence courses in 1994: "The province of jurisprudence determined - again!" (1995) 15 Legal Studies 88, 110-111. However, this represents a continuing decline in Austin's appeal, following a previous drop from 86 per cent in 1974 to 69 per cent in 1984. In contrast, Austin is only read in depth in 13 per cent of Australian jurisprudence courses; hence, Darwin was the more likely choice for capital city of the Northern Territory.

3 Scopes $v$ The State (1927) 154 Tenn (1 Smith) 105, 289 SW 363. See also Edward J Larson Summer for the Gods: The Scopes Trial and America's Continuing Debate over Science and Religion (Harvard University Press, Cambridge (Mass), 1997).

4 The production of groundbreaking research by future generations is constantly undermined by the overzealous scholarship of earlier generations. In the field of jurisprudence alone, all the leading theorists have been analysed to death, including many who are still alive. At this rate, the only advances in scholarship will have to come from reflective analysis of one's own work prior to publication.

5 The most notable recent events in Austinian scholarship are WL Morrison's study John Austin (Edward Arnold, London, 1982), Wilfrid E Rumble's The Thought of John Austin (Athlone Press, London, 1985) and his edition of The Province of Jurisprudence (Cambridge University Press, Cambridge, 1995). The first two contain extensive bibliographies of Austinian scholarship. Recent articles published since Rumble's edition include: Bruce D Fisher "The ethical consumer: a rejecter of positive law arbitrage" (1994) 25 
advancing an analysis of Darwin's influence on Austin. My analysis is not befuddled by the strong possibility that Austin had no knowledge of Darwin's theory of evolution. Indeed, On the Origin of Species was first published on 24 November 1859, a few weeks after Austin was stricken by illness that would shortly prove fatal. I doubt whether it would have found a place on Austin's death-bedside table. Nor is the absence of any evidence suggesting that Austin and Darwin had ever met at any other point particularly discouraging. ${ }^{6}$ After all, many great ideas in legal theory have taken wing on the basis of sheer hypothesis. ${ }^{7}$

How then would living next door to Darwin have influenced Austin's analysis in The Province of Jurisprudence? Part II Beyond the Boundaries of Jurisprudence, considers Austin's much-neglected category of metaphorical laws and the consequences a discussion with

Seton Hall L Rev 230; Michael Lobban "Was there a nineteenth century 'English school of jurisprudence'?" (1995) $16 \mathrm{~J}$ of Legal History 34; Mauro Barberis "Universal legal concepts? A criticism of 'general' legal theory" (1996) 1 Ratio Juris 1; W Michael Reisman "A jurisprudence from the perspective of the 'political superior'" (1996) 23 Northern Kentucky L Rev 605; Wilfrid E Rumble "Austin in the classroom: Why were his courses on jurisprudence unpopular?" (1996) $17 \mathrm{~J}$ of Legal History 17; Gerald B Wetlaufer "Gunmen, straw men, and indeterminacy: HLA Hart, John Austin, and the concept of law" (1997) 82 Iowa L Rev 1487; William MacNeil "John Austin or Jane Austen? The Province of Jurisprudence Determined in Pride and Prejudice" (1998) 4 Law-Text-Culture 1; Robert G Scofield "The conclusion of Austin's 'A Note on Interpretation': Is it missing or misplaced?" (1998) 19 J of Legal History 270.

6 Although Austin's wife Sarah maintained an extensive salon of prominent thinkers and literary figures, Darwin does not appear to have been among the guests: Lotte and Joseph Hamburger Troubled Lives: John and Sarah Austin (University of Toronto Press, Toronto, 1985).

7 For example, where would legal theory be today without the imaginative assistance of Hart's Rex dynasty, Dworkin's Hercules J, or Ross's Noît-cif tribe? (See Hart, above n 1, ch IV, Ronald Dworkin Law's Empire (Harvard University Press, 1986), and Alf Ross "Tû-Tû" (1957) 70 Harvard L Rev 812. Perhaps the best theoretical hypothetical is Lon Fuller "The case of the speluncean explorers" (1949) 62 Harvard L Rev 616-645, as proven by the fact that so many other theorists wish they had thought of it first. See the score of recent "decisions" in David L Shapiro "Foreword: A cave drawing for the ages" (1999) 112 Harvard L Rev1834; Alex Kozinski and others "The case of the speluncean explorers: Revisited" (1999) 112 Harvard L Rev 1876; Peter Stuber The Case of the Speluncean Explorers: Nine New Opinions (Routledge, New York, 1998); James Allan The Speluncean Case: Making Jurisprudence Seriously Enjoyable (Barry Rose Law Publishing, Chichester, 1998); Alexander M Sanders Jr "Newgarth revisited: Mrs. Robinson's case" (1998) South Carolina L Rev 407; JB Ruhl "The case of the speluncean polluters: Six themes of environmental law, policy, and ethics" (1997) 27 Environmental L 343; James Allan "A post-speluncean dialogue" (1994) $44 \mathrm{~J}$ of Legal Education 519; and Naomi Cahn and others "The case of the speluncean explorers: Contemporary proceedings" (1993) 61 George Washington L Rev 1754. Alternatively, the burgeoning of Newgarth jurisprudence may simply indicate that many theorists long to be judges. 
Darwin might have had on Austin's hierarchical classification. Part III On the Origin of Law, looks for proof of these consequences by means of a case study to explore whether metaphorical laws might evolve upwards through Austin's classification, attaining the befitting status of proper laws.

\section{BEYOND THE BOUNDARIES OF JURISPRUDENCE}

In The Province of Jurisprudence, Austin sets out a hierarchical classification of laws, based on an Aristotelian model of logic. His aim is to separate what he considers to be the core or essence of law from those phenomena that are improperly called law and that, therefore, obscure our understanding of the nature of law, that is to map out, by process of elimination, the boundaries of the province of jurisprudence. He concludes that only certain categories of man-made laws - positive laws and rules of positive morality amounting to express or tacit commands - are within the boundaries. However, "in order to describe the boundary which severs the province of jurisprudence from the regions lying on its confines, ${ }^{\prime 8}$ Austin discusses other categories of "laws", both those properly and those improperly so called. It is here, beyond the boundaries of jurisprudence, that Austin and Darwin meet.

Outside the boundaries of jurisprudence, but on a lower plain than that occupied by its man-made laws, Austin locates the metaphorical laws. As Austin describes, metaphorical laws result from the fact that "where ever we observe a uniform order of events, or a uniform order of co-existing phenomena, we are prone to impute that order to a law set by its author." ${ }^{9}$ However, he considers that it is inappropriate to use the word "law" in referring to the cause of such phenomena, not least because there is no element of sanction or duty attached to them. Metaphorical laws, therefore, are not laws but are only like laws, related to proper laws by a slender analogy. ${ }^{10}$ Thus far, Darwin is content to allow Austin to continue.

As a first example of metaphorical laws, Austin cites the uniform movement of lifeless bodies. The movement of a pendulum, he notes, is a phenomenon often described as governed by the laws of physics. While a lifeless body could be said to move in a uniform mode through "the pleasure and appointment of God" this is not the same as being governed

8 John Austin (HLA Hart ed) The Province of Jurisprudence Determined (Weidenfeld and Nicolson, London, 1968) 2. Unless otherwise noted, all further references to Austin are to Hart's edition.

9 Austin, above n 8, 173.

10 For more on the metaphorical value of law, see WH Auden's "Law Like Love" in Edward Mendleson (ed) Collected Poems (New Vintage International, New York, 1991) 262. See also Petersson's groundbreaking analysis in "Austin and Auden: The Journey Back to the Province of Jurisprudence", above n 4. 
by the operation of law. ${ }^{11}$ A lifeless body, he adds, has no desires which may be coerced by sanction nor has it any sense of obligation. ${ }^{12}$ Darwin begins to formulate an objection.

As a second example of metaphorical laws, Austin presents the actions of the "lower and irrational animals."13 Darwin is intrigued and holds back his objection. Austin offers two reasons to explain why animal conduct cannot be said to result from law. The first is that animals cannot understand the purpose and provisions of a law; the second is that animal conduct is based on instinct and experience and is neither motivated by duty nor coerced by sanctions. ${ }^{14}$ Though Austin recognises that some animals can be coerced by sanction and could be said to "understand and observe laws set to them by human masters", he rejects these examples for the sake of simplicity. ${ }^{15}$ The uniformity of animal conduct, he concludes, is merely another "effect of the Divine pleasure."16 Darwin interjects but Austin begs to be allowed to summarise the basis of metaphorical laws: ${ }^{17}$

11 Austin, above n 8, 173 .

12 A post-Austinian example proves this point. In 1897, the State of Indiana proposed legislation to change the value of pi from 3.14 to 4 , a more convenient figure in the days before calculators. However, pendulums in Indiana were not coerced by legal sanction and seemingly showed no sense of obligation to observe the new value of pi. They went about their business as before with the result that all clocks made with the new higher value of pi ran 15 minutes fast every hour, thus packing 30 hours in every day. The same phenomenon has been observed in law firms that operate on billable time, disproving the idea that lifeless bodies cannot be coerced by sanction.

Unfortunately, the Indiana pi law is a misleading example though it is convenient to repeat the error: see also DJ Whalan "The Potential Power of Committees in a 'Hung' Parliament" (1994) 8 Otago L Rev 151,162 . For reasons that escape common sense, the true story is that in 1897 State of Indiana proposed legislation to alter the value of pi from 3.14 to $16 / \sqrt{ } 3$ or 9.2376 , the grossest over-estimation since calculations began: Petr Beckman A History of Pi (Golem Press, Boulder (Colorado), 1971) 170-3. Bill 246 was passed unanimously by the State House of Representatives but did not get past second reading in the State Senate. That Bill 246 was never passed into law, however, has not dampened its use as an example of statutory futility. The failure of Bill 246 additionally stands as a testament to the value of bicameral legislatures.

13 Austin, above n 8, 174.

14 Austi, above n 8, 174

15 Austin, above n 8, 174, n 12

16 Austin, above n 8, 174.

17 Austin, above n 8, at 174 . 
In short, whenever we talk of laws governing the irrational world, the metaphorical application of the term law is suggested by this double analogy. The successive and synchronous phenomena composing the irrational world, happen and exist, for the most part, in uniform series: which uniformity of succession and coexistence resembles the uniformity of conduct produced by an imperative law. That uniformity of succession and coexistence, like the uniformity of conduct produced by an imperative law, springs from the will and intention of an intelligent and rational author.

Now invited to comment, Darwin counters with the observation that in both Austin's examples of metaphorical law, the "intelligent and rational author" is God. He recalls an earlier discussion where Austin asserted that "divine law is the measure or test of positive law and morality" [Darwin's emphasis] and that "law and morality, in so far as they are what they ought to be, conform, or are not repugnant to the law of God" [Austin's emphasis]. ${ }^{18}$ However, Darwin rationalises, once we question the divine origins of man we must also question any divine measure of man's laws. In other words, the category of metaphorical laws is meaningless if its basis is that such uniform phenomena can be traced to a divine author. Austin ponders his new neighbour's reasoning and begins to wonder if Bentham's influence has set him up as a straw man. ${ }^{19}$

Inspired by Darwin, Austin quickly realises that, once divine laws are discounted, the challenge is to determine the boundary between the laws of man and the laws of nature, admitting the possibility that the laws of man are not entirely removed from the instinctive basis of animal behaviour in the laws of nature. He reasons: ${ }^{20}$

It is true that the instincts of animal man, like many of his affections which are not instinctive, are amongst the causes of laws in the proper acceptation of the term. ... But nothing can be more absurd than the ranking with laws themselves the causes which lead to their existence. And if human instincts are laws because they are causes of laws, there is scarcely a faculty or affection belonging to the human mind, and scarcely a class of objects presented by the outward world, that must not be esteemed a law and an appropriate subject of jurisprudence. ${ }^{21}$

18 Austin, above n 8, 6.

19 After all, Bentham largely set himself up as a straw man. See CFA Marmoy "The 'auto-icon' of Jeremy Bentham at University College" (1958) 2 Medical History 77.

20 Austin, above n 8, 177.

21 Surely here Austin is ahead of his time in foreshadowing late $20^{\text {th }}$ Century critical scholarship. 
However, as Austin suggests, something more than mere instinct must lie at the heart of law's origin - something more is required in the distinction between proper and improper laws. Part III introduces a case study to explore what might distinguish proper from improper laws.

\section{ON THE ORIGIN OF LAWS}

The jurisprudential consequence of Darwin's work is that the origins of law must be considered to lie somewhere along the evolutionary path travelled by our ancestors. Consequently, it is possible to imagine a point in the irretrievably distant past at which our behaviour was subject only to instinct and the laws of nature, "laws" that Austin would originally have considered merely metaphorical. And yet, undisputably, we are now subject to laws properly falling within the boundaries of the province of jurisprudence. However, the temporal remoteness of our ancestral metaphorical laws bedevils an analysis of qualitative evolution in human law to confirm the intervening existence of metamorphorical laws. I therefore propose a non-human case study to look for proof of the potential for upwards movement of metaphorical laws.

In choosing an appropriate case study, I have been guided by Austin's own examples of metaphorical laws. I have avoided examples based on the movement of lifeless bodies, as they do not respond to accommodate our desires. ${ }^{22}$ At the other end of the metaphorical laws spectrum, we find that certain animals such as dogs do, in fact, modify their behaviour to accommodate our desires. I have, therefore, chosen to look at the behaviour of bees as an example lying somewhere in between these two extremes. I do not mean to suggest that what goes on within the beehive amounts to rational law making for a civilised society. However, the example of bees offers insight into the conditions that might distinguish laws proper from laws improper.

Bees live together and operate as a group, rather than as isolated individuals. This social nature increases the likelihood that their behaviour may be governed by more than basic instincts. Bees also have a highly evolved language of "dances" that has been described as "the second most complicated language in nature". ${ }^{23}$ Indeed, given their social and

22 As the Indiana pi law demonstrates, lifeless bodies such as pendulums do not modify their behaviour according to our laws. See above $\mathrm{n} 12$.

23 James Gould and Carol Grant Gould The Honey Bee (Scientific American Library, New York, 1988 ) 69. The Goulds do not expressly state which natural language is the most complex. On the basis of the unnatural phoneme of a palatal n, I would have suggested Icelandic. 
communicative nature, descriptions of bee society could easily be mistaken for our own were apian references to be removed. For example: ${ }^{24}$

The whole fabric of honey bee society depends on communication - on an innate ability to send and receive messages, to encode and decode information. Only by speaking the same language from the outset can a colony of as many as 60,000 short-lived individuals coordinate its efforts and avert chaos.

One of the central roles served by the bees' language is to bespeak the existence and location of food. The bees' language is sufficiently evolved to communicate abstracted information regarding food found away from the hive and at an earlier point in time. For example, when a bee has found food away from the hive, she will indicate its location to other bees by doing the "waggle dance", repeatedly marking out a figure-eight on the inside wall of the hive. ${ }^{25}$ The straight-run of the eight indicates the direction from the hive in the horizontal plane, as if the dancing bee had drawn a "map" on the vertical wall of the hive. The other bees read the map according to the convention that the sun is at the top of the vertical plane, just as our convention posits North at the top of our maps. The line of the dance therefore indicates the food's location in relation to the sun. The food's distance from the hive is indicated by the speed of the dance and by peeping noises made by the bee. To put it in non-legal terms, distance is inversely proportional to speed and to the logarithm of the rate of peeping. ${ }^{26}$ However, using the vertical plane to represent the direction of the sun is only one version of the waggle dance, a version necessitated because the hive is usually dark. If there is a light source in the hive, bees orientate the waggle dance to the light source rather than using the convention of the vertical plane.

Thus far, however, the language and behaviour of bees suggests nothing more than a further example of Austin's metaphorical law. The bees' behaviour is governed by instinct and experience. Even though the instinctive and experienced behaviour of bees produces conduct that is in the best interests of the hive this is not nearly enough to be characterised as

24 Gould above n 23, 47. See also Bernard Mandeville's classic political satire: FB Kaye (ed) The Fable of the Bees (Clarendon Press, Oxford, 1924). But see Aristophanes The Wasps.

25 In contrast, if food is close to the hive, the bee who found it will do "round dance" when she returns to the hive. The foundational research on the language of bees was under taken by Karl von Frisch. See The Dance Language and Orientation of Bees (Harvard University Press, Cambridge, 1967).

26 Richard Dawkins River Out of Eden (Basic Books, New York, 1995) 87. In plain English, the faster and noisier the dance, the closer the food. 
law. It is merely uniform conduct that resembles conduct governed by law and thus remains at the metaphorical level. As Austin concluded, instinct might cause law but it is not itself law. To be able to state that laws have evolved above the metaphorical level, therefore, behoves more evidence than just hungry bees. A slight change in circumstances, however, provides a further step towards law.

The bees' language has evolved because the ability to communicate the location of food is in the best interests of the hive. However, a society where all individuals instinctively act in a manner that promotes the common good is an ill-suited basis on which to advance our understanding of law. There is more to be gained by the study of societies where individual behaviour runs contrary to the common good. It is possible to produce such behaviour in bees by introducing a simple variation into the previous example - bees can be made to lie. Returning bees were belayed at the entrance to the hive and their eyes painted over with black paint. The blind bees were then allowed into the hive but could not see that a light had been turned on inside. The blind bees proceeded to do the waggle dance as if it were dark in the hive, using the vertical plane to indicate the direction of the food. However, the sighted bees read the dance in relation to the light source inside the hive and made a beeline in the opposite direction. Having been forced to lie, the blind bees had unwittingly sent their colleagues off on a wild flower chase.

We must bemoan the fact that the researchers paid little attention to the interdisciplinary potential of their experiment. Had they but harkened to Hart's befitting words: ${ }^{27}$

They throw a light which makes us see much in law that lay hidden; but the light is so bright that it

blinds us to the remainder and so leaves us still without a clear view of the whole.

The world of jurisprudence would have been abuzz had they only recorded what befell the bees who blindly lied to the hive. Were, for example, the blind bees punished? If so, did it make the other bees wary? Was the punishment merely the outcome of instinctive behaviour by the other bees? If instinctive, what further conditions are required for the bees to distinguish between strict liability offences and those that consider intent? What is it that allows us to distinguish between punishment that is merely instinctive and punishment that might be said to result from the operation of law, between the causes of law and law itself? What lies between the region of metaphorical laws and the boundary of the province of jurisprudence?

27 Hart, above n 1, 2 
As noted earlier, for mankind the answers to such questions lie in the irretrievably distant past. Our best hope to truly understand law is to watch for its evolution in other species. However, as regards interdisciplinary research, most jurisprudes are drawn only by the beacon of social science, while, for their part, natural scientists rarely regard working with lawyers as the bee's knees. Thus, it is unlikely that empirical research will be carried out to establish that proper laws evolve from improper once and the intervening existence of metamorphorical laws. Yet the simple example of bees suggests minimum conditions for the evolution of law, conditions too obvious to belabour here. Perhaps all will become clear when behaviourist Konrad Lorenz befriends Austin. ${ }^{28}$

\section{CONCLUSION}

A sociologist is once reported to have concluded that it takes 150 years for 90 per cent of the population to accept a fundamental challenge to long held beliefs. ${ }^{29}$ The extreme nature of Darwin's challenge to our beliefs is reflected in the slow progress of acceptance against the timeline of resistance. Approaching the sesquicentennial mark, only 12 per cent of Americans accept a strict interpretation of Darwin's theory of evolution, though a further 37 per cent accepted an interpretation that involved God guiding evolution; 45 per cent retained a strict creationist belief. ${ }^{30}$ That Austin took little account of Darwin's theory is understandable; he died only a few weeks after Darwin's publication of Origin of the Species and well before the 1871 appearance of The Descent of Man. However, the anachronistic scenario of Darwin replacing Bentham as Austin's influential neighbour suggests interesting consequences for Austin's classification of laws. Discounting divine laws, Austin's challenge is to distinguish between the laws of man and laws of nature. Recognising that the laws of man must at an

28 In 1973, Lorenz received the Nobel Prize for Medicine, an award he shared with bee researcher Karl von Frisch.

29 I have not been able to trace the source of this useful conclusion. I asked a sociologist colleague if she was familiar with the study. She replied that "No sociologist would say that. It has numbers in it! As a statement it doesn't make sense - what does it mean by challenge to beliefs? Does it mean changing existing ones? What types of beliefs? What type of challenge? It's meaningless. It was probably a lawyer attributing nonsense to a sociologist." Thus I am left to rely on the hearsay account and assume it to be at least as accurate as the Indiana pi law example.

30 Deborah Jordan Brooks "Substantial numbers of Americans continue to doubt evolution as explanation of origins of humans" (5 March 2001) Press Release <www.gallup.com/poll/releases/pr010305.asp>. The survey used a random telephone survey of 1,000 adults, 18 years and older and was conducted 1921 February 2001. The survey results show little change from previous surveys over the past 20 years. 
earlier point themselves have been laws of nature suggests that the quality of a law can change, that is that improper laws may evolve to the level of proper laws. 